\title{
STUDY ON PRIMING METHODS TO ENHANCE THE VIABILITY AND VIGOR OF TREMA (Trema orientalis Linn. Blume) SEEDS
}

\author{
Naning Yuniarti*, Rina Kurniaty and Dida Syamsuwida \\ Forest Tree Seedling Research Institute \\ Jl. Pakuan, Ciheuleut, Bogor, West Java, Indonesia
}

Received: 21 September 2017, Revised: 10 April 2019, Accepted: 30 April 2019

\begin{abstract}
STUDY ON PRIMING METHODS TO ENHANCE THE VIABILITY AND VIGOR OF TREMA (Trema orientalis Linn. Blume) SEEDS. Trema is one of tropical forest trees that have many advantages such as wood for construction, pulp and charcoal, leaves for medicine and bark for dye material. One constrain of the development of this species is the difficulties of the germination of the seeds and rapid seed deterioration after storing. Therefore, there should be found a method to solve the problem. This paper determines the proper method of priming to enhance the viability and vigor of Trema seeds after storage. Randomized Complete Design was employed in this trial by priming the seeds before and after storage. The treatments were priming methods including: control (no priming), matriconditioning with ash, osmoconditioning by soaking into $5 \% \mathrm{H}_{2} \mathrm{O}_{2}$, humidify with water and hydrated-dehydrated process. The observed parameters were germination percentages, speed of germination, mean daily germination, germination value, and growth uniformity value. Results show the best treatment method for priming of seed of trema, both before storage and after storage is the treatment of hydration-dehydration. All the observed parameters gave increased values after using such treatment. Before storage, it could increase the value of germination percentage and speed of germination by $15 \%$ and $0.9 \%$-etmal , respectively. After storage, treatment hydration-dehydration could increase the germination by $17 \%$ and the speed of germination by $1.25 \%$-etmal.
\end{abstract}

Keywords: Trema seed, priming, viability, vigor

PENELITIAN PENENTUAN METODE PRIMING UNTUK PENINGKATAN VIABILITAS DAN VIGOR BENIH TREMA (Trema orientalis Linn. Blume). Trema adalah jenis tanaman yang termasuk tanaman serba guna. Kayunya digunakan untuk kayu pertukangan, industri kertas dan arang kayu. Daun dan batangnya dapat dijadikan obat herbal, dan kulit batangnya untuk. bahan pewarna. Permasalaban pengembangan jenis ini mempunyai adalah yaitu lamanya waktu berkecambah serta viabilitas dan vigor benibnya mengalami penurunan setelah penyimpanan. Sehingga diperlukan perlakuan yang dapat mempercepat perkecambahan dan meningkatkan viabilitas dan vigor, yaitu dengan metode priming. Tujuan penelitian ini adalah diperolehnya metode priming yang tepat untuk meningkatkan viabilitas dan vigor benib trema setelah penyimpanan. Benih trema yang digunakan dalam penelitian ini berasal dari Bali. Rancangan percobaan dalam penelitian ini menggunakan rancangan acak lengkap (RAL) dengan menggunakan perlakuan priming pada benih sebelum disimpan dan sesudah penyimpanan. Perlakuan priming yang digunakan terdiri dari: kontrol, matriconditioning abu gosok, Osmoconditioning dengan perendaman $\mathrm{H}_{2} \mathrm{O}_{2} 5 \%$, perendaman/pelembaban dengan air, dan bidrasi-debidrasi. Untuk perlakuan kontrol (tanpa perlakuan priming), benih langsung dikecambabkan. Parameter yang diamati yaitu daya berkecambah, kecepatan berkecambah, kecambah harian rata-rata. Nilai perkecambahan dan nilai keserampakan tumbuh. Hasil penelitian menunjuk.kan bahwa perlakuan metode priming terbaik, baik sebelum disimpan maupun sesudah penyimpanan yaitu perlakuan bidrasi debidrasi. Semua parameter yang diamati memperlihatkan peningkatan setelah diperlakukan dengan metode priming tersebut. Sebelum disimpan, dapat meningkatkan nilai daya berkecambah dan kecepatan berkecambah masing-masing 15\% dan 0,9\%/-tmal. Setelah penyimpanan, perlakuan hidrasi dehidrasi dapat meningkatkan daya berkecambah 17\% dan kecepatan berkecambah 1,25\%/-etmal.

Kata kunci: Benih, trema, priming, viabilitas, vigor

${ }^{*}$ Corresponding author: naningbtp@yahoo.co.id 


\section{INTRODUCTION}

The success of a plantation program is strongly dependent on its cultivation and the use of qualified seeds, which definitely have to be conditioned to achieve good seedlings that expected to give excellent stands. One of the prospective woody species to be developed in a plantation program is Trema (Trema orientalis Linn. Blume).

Trema is a multi-purpose species because all parts of the tree can be utilized for many purposes. The wood is flammable when dry and contains $4,576 \mathrm{cal} / \mathrm{g}$ of energy (Rostiwati et al., 2006). The wood can also be used for tools, construction, pulp and paper, veneers, matches and charcoal. The leaf is good for pharmaceuticals as herbal and it is useful as well for animal feeds (Kurniaty et al., 2015). However, the development of the species faces some problems concerning the viability of the seeds which takes long time to germinate and the rapid deterioration of the seeds after storage (Panjaitan, 2010). The seed of Trema is physiologically categorized as intermediate (Kurniaty et al., 2015). The quality of intermediate seeds will decrease gradually and this happens naturally. Seed quality is dependent upon initial seed quality, temperature, moisture content and mycoflora. Rapid deterioration occurs due to these environmental conditions which make it very difficult to keep the viability during storage (Jyoti \& Malik, 2013). After storage, the metabolism activities in the seed will decline and the viability of the seeds will eventually diminish (Kurniaty et al., 2015).

To enhance the declining seed qualities and get high viability and vigor of the seeds after storage, priming is the solution (Moradi \& Younesi, 2009). Priming is a pre-treatment that control the rate of water intake by the seed, augment the mitochondria activity through biosynthesis process and the defensive of cell ultra-structures that make the seeds more standed to the pressure and enable to stimulate the growth easily (Zanzibar, 2010). Priming the seeds can be carried out through hydropriming that is a way of soaking seed by using a specific solution (Halimursyadah \& Murniati, 2008). Priming will function on seeds to increase uniformity of germination and emergence from the soil, and thus enhance stand establishment (Hill, 2018). Priming treatment can increase plant resistance to environmental stress, sub optimum, at low temperatures (Farooq et al., 2007), it is also effect on drought stress which was reported by Farooq et al. (2009).

One of the priming techniques is osmoconditioning (Rusmin, 2007). Osmoconditioning is a regular process of water absorption (imbibition) by the seed, using a solution that has a lower osmotic potential as a media of imbibition. Osmoconditioning aims to speed up germination time, synchronize germination and improve the percentage of normal germination (Yuanasari et al., 2015). To increase the ability of seed germination, the seeds can also be treated with low matrix potential media or matriconditioning media (Gholami et al, 2009; Mia et al., 2010).

Apart of increasing the physiological quality of seeds, the methods of priming will result a physically better performance of the seed, it will be more fresh and brighter in color. The priming technique is applicable and affordable that makes it suitable to be a standard in handling of forest tree seeds (Zanzibar, 2010). Priming treatments (seed hydration during a specific time followed by seed dehydration) could be an alternative germination pretreatment to improve plant establishment. Natural priming (via seed burial) promotes rapid and synchronous germination as well as the mobilisation of storage reserves; consequently, it increases seedling vigor (Lopez, 2014).

Naturally, seed is deteriorating over time. Seed deterioration during a period of storage is a chronological decline in term of time and physiological decline due to various environmental factors. Seed deterioration is a decrease of seed viability caused by the overall changes of seed cells and tissues either physically, physiologically or chemically. Deterioration is characterized by the decline of seed germination, increase of abnormal 
germinated seedlings, decrease of field emergences, impaired growth and development of plants, increase of sensitivity towards extreme environment (Panjaitan, 2010). Priming is often used to re-increase the viability of seeds that have been reduced. Priming is also used for lengthening the storability of the seeds, thus it can maintain the viability and vigor of the seeds during storage (Utami et al., 2013).

The main purpose of the priming is to increase the viability and vigor of aging seeds, as well as to make seedlings more competitive and tolerant to sub-optimum conditions. This method is suitable to be applied to the seeds that have slow germination and rapid deterioration.

Seeds of Trema have a problem with their germination that takes long time to sprouts due to the dormant characteristic of the seeds (Yuniarti \& Kurniaty, 2016). By using priming method, it is possible to speed up the time of seed germination and enhance the germination percentage. Hence the objective of the research was to determine the appropriate priming methods to enhance the viability and vigor of Trema (Trema orientalis Linn. Blume) seeds after storage.

\section{MATERIAL AND METHOD}

\section{A. Location}

The study was carried out in the laboratory and greenhouse of Forest Trees Seed Technology Research Centre in Bogor for four months from February to May 2015. The equipments included storage room at temperature of $27-29^{\circ} \mathrm{C}$, germination beds, media of sterilized soil and sand.

\section{B. Fruit Collection and Seed Extraction}

Fruit of Trema was collected from Badung District, Bali Province in February, 2015. The materials for the trials were ash and $\mathrm{H}_{2} \mathrm{O}_{2}$ (Hydrogen Peroxide) (Zanzibar, 2010; Zanzibar, 2011). The fruits of Trema were collected by climbing the trees and cutting the fruit bearing branches using a pole with hooked pruner. Five sample trees were used to collect the fruits. Seeds were extracted by crushing the surface of the fruit with coarse sand, and washed under tap water, until the pulp and testa were removed. The cleaned seeds were then wind dried under shaded place.

\section{Priming Treatments}

There were two trials of treatments, i.e :

\section{1) Priming before storage}

The treatments used were matriconditioning with ash, soaking and/or moistening with water and hydrating-dehydrating. Seeds with no treatments were directly germinated.

Ash matriconditioning was carried out in a petri dish by placing a mixture of ash, seeds and water with a comparison of 4:1:1 (v/v). The mixtures were stirred evenly, then stored in an ambient room temperature $\left(27-29^{\circ} \mathrm{C}\right)$ for $3 \mathrm{x}$ 24 hours and moistening with water every day.

Osmoconditioning with $5 \% \mathrm{H}_{2} \mathrm{O}_{2}$ : seeds were put in a beaker glass filled with a solution of $5 \% \mathrm{H}_{2} \mathrm{O}_{2}$ and water in a comparison of $3: 1$ $(\mathrm{v} / \mathrm{v})$. The mixtures were placed in an ambient room temperature $\left(27-29^{\circ} \mathrm{C}\right)$ for $3 \times 24$ hours. Osmoconditioning by moistening the seeds: Seeds were arranged on a moist paper in a petri dish and placed in a germinator for $3 \times 24$ hours.

Hydration-dehydration : Seeds were put in a beaker glass, soaked with water for 24 hours, then wind dried at room temperature for 24 hours. The treatment was repeated 7 times, using fresh water in every treatment.

When all the priming treated seeds was done, the seeds were washed under tap water for 3-4 minutes and germinated in seed beds filled with a mixture media of soil and sand (1 : 1), then placed under greenhouse condition. The number of seeds for each treatment was 100 seeds with 4 replications.

The observation was carried out once the seedlings germinated, normally marked by the raising of a pair of leaves. The parameters observed were germination capacity, speed of germination, mean daily germination, germination value, and growth uniformity value.

2) Priming after storage

The fresh seeds were put in plastic 
containers stored under room temperature for one month. After being stored, the seeds were treated with priming methods as it was done above in point a). The trial was only conducted within 1 month storage due to the limitation of the seeds for research material. The parameters observed were germination capacity, speed of germination, mean daily germination, germination value, and growth uniformity value.

\section{Design Experiment}

Both trials were designed using Completely Randomized Design (Steel \& Torrie, 1995) with priming methods as treatment factors, namely: matriconditioning with ash, soaking and/or moistening with water, and hydratingdehydrating. Deuteronomy 4 times@100 seeds.

\section{E. Data Analysis}

A completely randomized design (CRD) with priming methods as treatment factors. Data were analyzed by using analysis of variance (ANOVA). If there was a significant effect that was followed by Least Significant Difference (LSD) test.

\section{III.RESULTS AND DISCUSSION}

\section{The Germination Percentage}

The result of variance analysis of the influence of priming before (0 month) and after storage (1 month) on the capacity of germination of Trema seeds is presented in Appendix 1 and 2.

Based on the analysis of variance, priming treatments before and after storage, influenced significantly the values of germination percentage of Trema seeds. The differences were tested by Duncan's (Figure 1).

Before and after storage treatments, the priming seeds of hydrated-dehydrated method resulted in the highest germination capacity of $89 \%$ for those seeds before storage and $78 \%$ for seeds after storage. Thus, it increases the germination capacity of about 15\% before storage and $17 \%$ after storage compared to control (Figure 1).

For Trema seeds, hydro-priming is the most appropriate method to increase the germination capacity. Studies have shown that seed priming can be used to improve germination, accelerate seedling emergence time, as well as increase seed longevity during storage and yield (Khan,

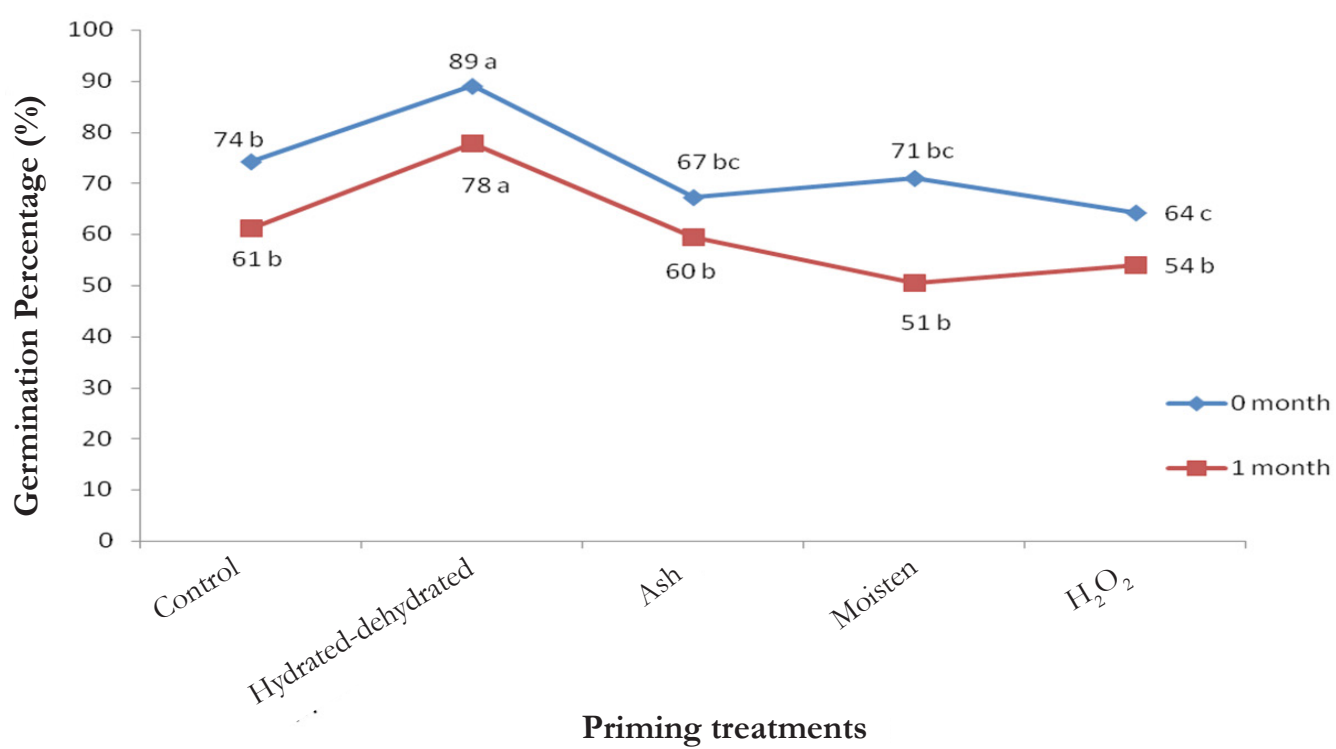

Figure1. Mean values of germination percentage of Trema seeds and their differences test in relation to the priming before and after storage

Remarks: values followed by the same letters are not significantly difference at a confidence level of 95\% 
1992). This is because hydro-priming increases the level of metabolites associated with the germination process and enzymes associated with the production of energy that allows the seeds to quickly reach a high level of moisture with a constant supply of oxygen (Duffus \& Slaugther, 1985). However, according to Rodriguez et al. (2015) hydro-priming should be undertaken with care in case seeds are infected with pathogens. According to Hadinezhad et al. (2013) hydro-priming is used as a pre-sowing or mid-storage treatment for seeds that have lost their vigor due to improper storage conditions. In the case of Trema seeds, the hydration-dehydration treatment caused increased germination capacity for those seeds that have not been stored previously. It was observed that seeds of Pongamia pinnata had the highest germination, shoot length, root length, germination rate index and seedling dry weight after being hydrated for 16 hours (Ramensh, 2007).

Figure 1 also show priming treatments of ash matriconditioning, osmoconditioning with $5 \% \mathrm{H}_{2} \mathrm{O}_{2}$, and immersing and/or moisturizing with water, resulting in lower values of germination capacity than control. In this case, there might be some reasons to explain it. According to Ruliansyah (2011) the use of rubbing ash as a media of matriconditioning caused damage to the seed coat, as the media contains silica element that is sharp enough to injure the coat when ash, water and seeds were mixed. The damaged seed coat would eventually affect the germination process that decreasing the viability of the seeds. Zanzibar (2017) mentioned that the use of hydrogen peroxide $\left(\mathrm{H}_{2} \mathrm{O}_{2}\right)$ at $5 \%$ concentration was adversely affecting the germination. In fact, the use of $\mathrm{H}_{2} \mathrm{O}_{2}$ can cause interference or damage to the seed embryo. Mostly, the method of seed testing using $\mathrm{H}_{2} \mathrm{O}_{2}$ uses a concentration of $1 \%$ to $3 \%$ and preferably in a stable form. Concentration above $1 \%$ of $\mathrm{H}_{2} \mathrm{O}_{2}$, usually may still adversely affect to the germination. In term of priming techniques using moist method, according to Zanzibar \& Mokodompit (2007) the priming should consider the level of seed coat hardness. The hard seed coat of Trema is more suitable to use immersion than by moisturizing the seeds.

\section{The Speed of Germination}

The result of variance analysis of the influence of priming before ( 0 month) and after storage (1 month) on the speed of germination of Trema seeds is presented in Appendix 3 and Appendix 4. Based on the analysis of variance, priming treatments before and after storage, influenced significantly the values of speed of germination of Trema seeds. The differences were tested by Duncan's (Figure 2).

Before storage, the priming method of hydrated-dehydrated was enable to increase the speed of germination by about $0,9 \%$-etmal from control. The highest value of speed of germination rate $(3.63 \%$-etmal was those of fresh seeds treated by hydrated-dehydrated treatment. (Figure 2). Fujikura et al. (1993) demonstrated that hydropriming produced great improvement in the rate of germination, even more than osmo-priming, in cauliflower (Brassica oleracea L.). Contrary, Tian et al. (2014) mentioned that the seed of maize (Zea mays $\mathrm{L}$.) was reduced in germination rate after water priming compared to reagents priming of GA at $10 \mathrm{mg} / \mathrm{L}, \mathrm{NaCl}$ at $50 \mathrm{mM}$, and PEG at $15 \%$.

Deterioration of seed is impossible to stop but it can be delayed. One way to do such delay is through a hydration-dehydration (priming) treatment (Zanzibar \& Mokodompit, 2007). In principle, priming activates the internal energy sources of the seed (viability and seed vigor) and external energy sources (optimum germination condition). A proper priming given to the seeds will stimulate the growth of sprouts, brake the dormancy and decrease the sprouts mortality (Zanzibar, 2010).

It was shown in Figure 1 and 2 that before being stored, the best priming for Trema seeds was hydrated-dehydrated treatment. The germination capacity and speed of germination was $89 \%$ and $3.63 \%$-etmal , respectively. Thus, priming method of hydrated-dehydrated would 


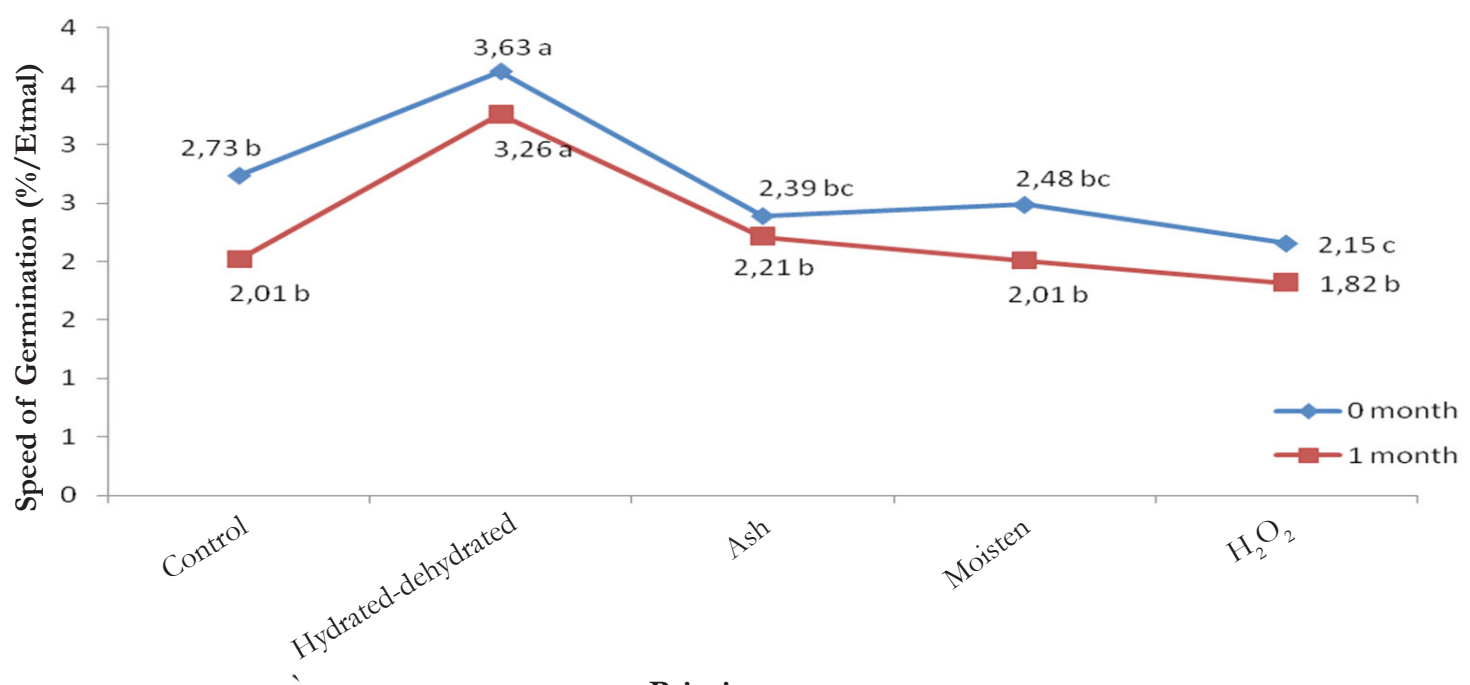

Priming treatments

Figure 2. Mean values of speed of germination of Trema seeds and their differences test in relation to the priming before and after storage.

Remarks: values followed by the same letters are not significantly difference at a confidence level of 95\%

be able to enhance the capacity and speed of germination by up to $15 \%$ and $0.9 \%$-etmal compared to control, respectively. Unlikely, hydrated followed by dehydrated in bean (Phaseolus vulgaris) seeds treatment was the possible cause of the decrease of germination rate (Abebe \& Moddy, 2009).

After storage, the priming method of hydrated-dehydrated was enable to increase the speed of germination by about 1,25\% $\%^{\text {-etmal }}$ from control. The highest value of germination speed was those of fresh seeds treated by hydrated-dehydrated treatment. (Figure 2).

After storage, the priming method of hydrated-dehydrated was enable to increase the speed of germination for about 1,25\% $\%^{\text {etmal }}$ increment from control. The highest value of speed germination was those fresh seeds treated by hydrated-dehydrated treatment. (Figure 2).

The storage was carried out for 1 month only because there was a limitation of the seeds for research material. After storage for one month, it was found that the best priming method was also the hydrated-dehydrated treatment that could increase the germination capacity up to $17 \%$ and speed of germination by $1.25 \%$ etmal compared to control. Therefore, this method would be able to lengthen the storability of Trema seeds. Ibrahim et al. (2013) stated that upland rice (Oryza sativa) seeds can successfully be hydro primed for 12 hours and dehydrated the seeds by drying for 4 hours to get better germination and growth performance. Contrary to this finding, Abebe \& Modi (2009) reported the failure of germination after hydrating the seeds of Phaseolus vulgaris for 4 and 8 hours. This might happen due to different characteristics of seed species, size of the seed, coat thicknesses that might get different cotyledonal cracking and higher leakage of nutrition (Mazibuko \& Modi, 2005, Quan et al. 2004).

Hydrated-dehydrated treatment is capable to serve the requirement of optimum water from the time of imbibition to the end of activation process that is closed to the water potential at a room temperature. If the seeds were water saturated, then wind-dried, the seeds would release the water slowly and this condition was good for repairing deteriorated tissues. The refinement mechanism of deteriorated tissues occur simultaneously of which the seeds achieve their water content balance. In this condition the seeds will be trying to heal 
themselves (Schmidt, 2000).

The priming is capable as well to break a dormancy. The circumstance condition of moist and dry surrounding the seeds will stimulate the embryo to continue their maturation (after ripening). This has been happening on kesambi (Scheleria oleosa) and teak (Tectona grandis) seeds (Zanzibar et al., 2008). According to Zanzibar (2010), the treatment of soaking was suitable for those seeds with a hard coat, meanwhile the treatments of hydrated-dehydrated and ash or sawdust matriconditioning were good for thin coat seeds.

Hydropriming, priming in $\mathrm{CaCl}_{2}, \mathrm{KNO}_{3}$, and ascorbic acid solution increased vigor index and speed of germination of long bean seeds. The advantages of these treatments could be maintained until 15 weeks of storage both in AC and ambient temperature. Hydropriming was the best choice for seed treatment before storage because it is cheap and easy to perform (Utami et al., 2013).

The moist and dry treatment that was repeated several times will become a recovering mechanism of natural ageing and /or physical damage during seed handling. After controlling the rate of imbibition, priming will be activating the metabolism elements to start the process of germination. In addition, the radicle will be extending until the end of the activation phase. The treatment is discontinued before reaching the limit conditions of seed damage tolerance. Then, the priming seeds can be dried either to be stored, distributed or planted.

The use of hydrate-dehydrated technique is applicable on a large scale, because of being affordable and easy to be practiced. The proper priming will manage the requirement rate of seed water during germination and speed up the metabolism rate. This condition may cause the prolongation of the activity phase, giving physiologicalrefinementto the seeds Thepriming will improve the activity of protease enzyme and the ability of embryo to synthesize protein and RNA, making it more resistant to unfavourable environmental condition. The priming can be done in two ways: osmoconditioning and matriconditioning. Mostly, forest tree seeds that have been deteriorating physiologically, their quality might be increased by using priming of osmocondition (moistening within a certain solution) or matricondition (moistening with ash or sawdust) (Zanzibar et al., 2011).

\section{The Mean Daily Germination}

The result of variance analysis of the influence of priming before ( 0 month) and after storage (1 month) on the mean daily germination of Trema seeds is presented in Appendix 5 and Appendix 6.

Based on the analysis of variance, priming treatments before storage influenced significantly, but after storage not significantly on the values of mean daily germination of Trema seeds. The differences were tested by Duncan's (Figure 3).

It was revealed that the seeds treated by priming with hydrated-dehydrated method before storage resulted in high value of mean daily germination (1.26\%) and was significantly different compared to the other treatments. Meanwhile, treatments after storage showed that there was no difference of mean daily germination among treatments (Figure 3).

Mean daily germination is an average of germination percentage every day obtained from the value of germination percentage at the end of the observation divided by the number of testing day or the last germination day (Gairola, 2011). The mean daily germination indicates the ability of seeds to germinate at any day (Hidayat, 2007). This means that priming treatment of hydrated-dehydrated method is able to optimize the ability of seeds to germinate every day compared to the other treatments of priming.

\section{The Germination Value}

The result of variance analysis of the influence of priming before ( 0 month) and after storage (1 month) on the germination value of Trema seeds is presented in Appendix 7 and Appendix 8.

Based on the analysis of variance, priming treatments before storage influenced 


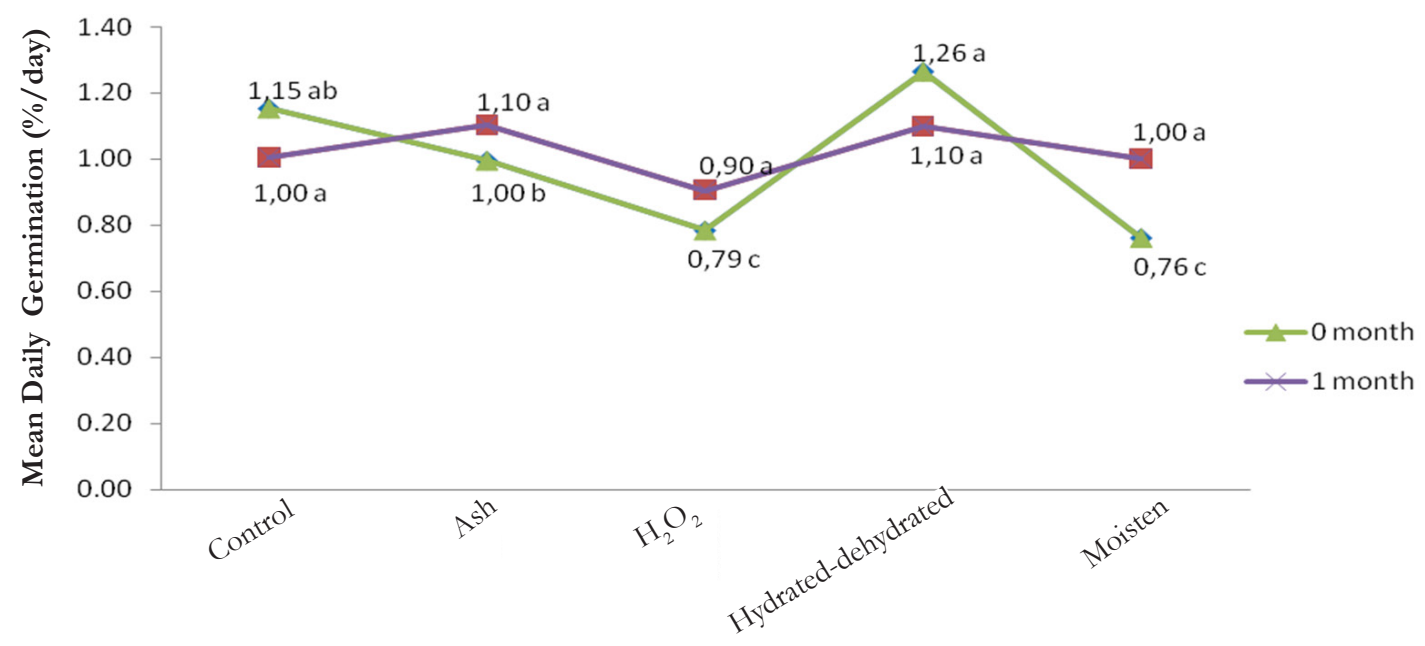

Priming treatments

Figure 3. Mean values of the mean daily germination of Trema seeds and their differences test in relation to the priming before and after storage

Remarks: values followed by the same letters are not significantly difference at a confidence level of 95\%

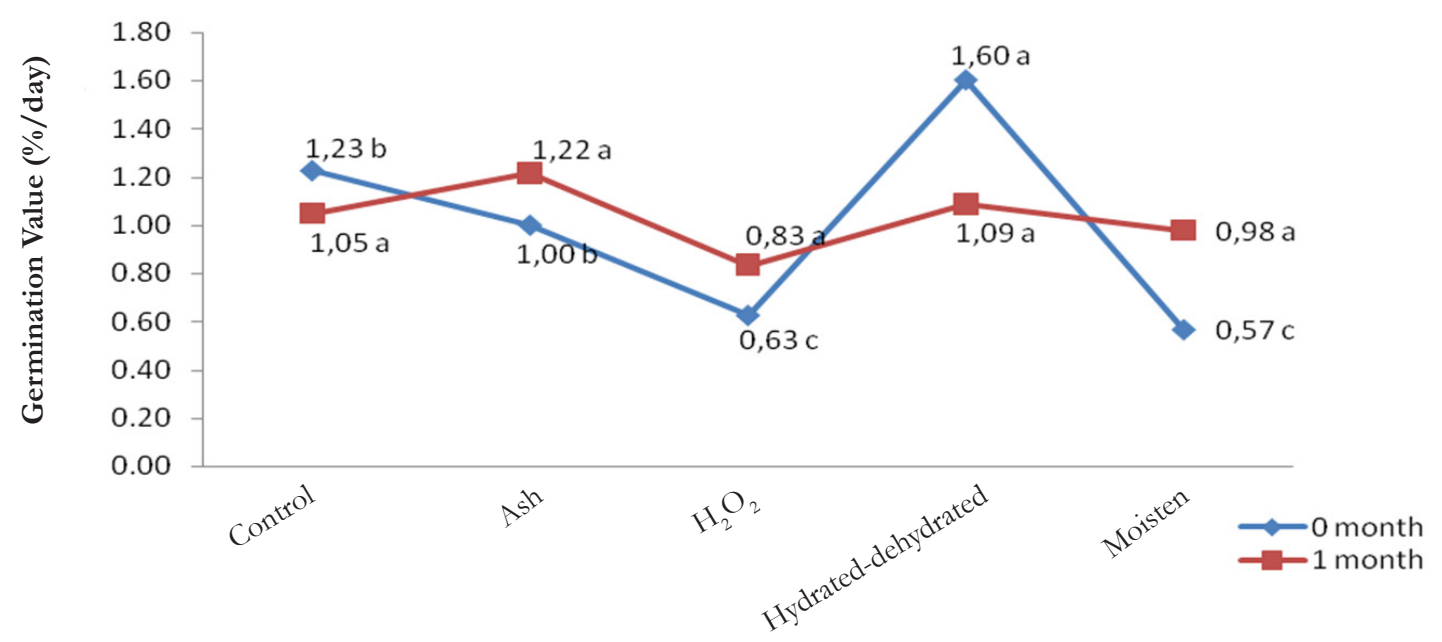

Priming treatments

Figure 4. Mean values of the germination value of Trema seeds and their differences test in relation to the priming before and after storage

Remarks: values followed by the same letters are not significantly difference at a confidence level of $95 \%$

significantly, but after storage not significantly on the germination value of Trema seeds. The differences were tested by Duncan's (Figure 4).

Before storage, seeds treated by hydrateddehydrated priming gave the highest germination value $(1.60 \%)$ which is significantly different with the others. After storage, the germination value did not give significant difference among all the treatments (Figure 4).

The germination value is obtained from the multiplication of germination peak value with mean daily germination. Germination peak value (the energy) is closely related to the germination percentage and germination rate values. The 
faster the germination rate, that accompanied by a high germination percentage, the higher the peak value. This is due to that peak value was achieved from the result of dividing the germination percentage by the number of days needed to reach such germination percentage. A high germination value indicates a good seed vigor which is showing perfection of seed viability. Germination peak value shows the energy (power) of maximum seed germination obtained in a quick certain time. Basically, germination power of a seed lot follows a normal curve pattern. At the first phase it will increase significantly up to reaching a maximum point, then it will decrease eventually (Hidayat, 2007).

\section{The Growth Uniformity Value}

The result of variance analysis of the influence of priming before ( 0 month) and after storage (1 month) on the growth uniformity value of trema seeds is presented in Appendix 9 and Appendix 10.

Based on the analysis of variance, priming treatments at before and after storage influenced significantly on the values of the growth uniformity value of trema seeds. The differences were tested by Duncan's (Figure 5).

In the treatments of before and after storages, it was known that the seeds treated by priming with hydrated-dehydrated method was able to produce a highest growth uniformity that is $74.75 \%$ (before storage) and $72 \%$ (after storage) compared to other treatments (Figure 5). So that, the treatment of hydrateddehydrated was the best priming method to be used for trema seeds shown from all parameters measured.

Growth uniformity of germinating seeds is the ability of a seed lot to germinate simultaneously in a certain time. This parameter is one of vigour tests of seed germination capacity. The test gives a real percentage of seeds that capable to germinate normally in the field when the condition was optimum. The growth uniformity indicator identifies the seed vigour of lot seeds, although the growth rate is measured as the percentage of seedlings or normal germination toward all the seeds planted for the specified time (Damanik, 2010).

\section{CONCLUSION}

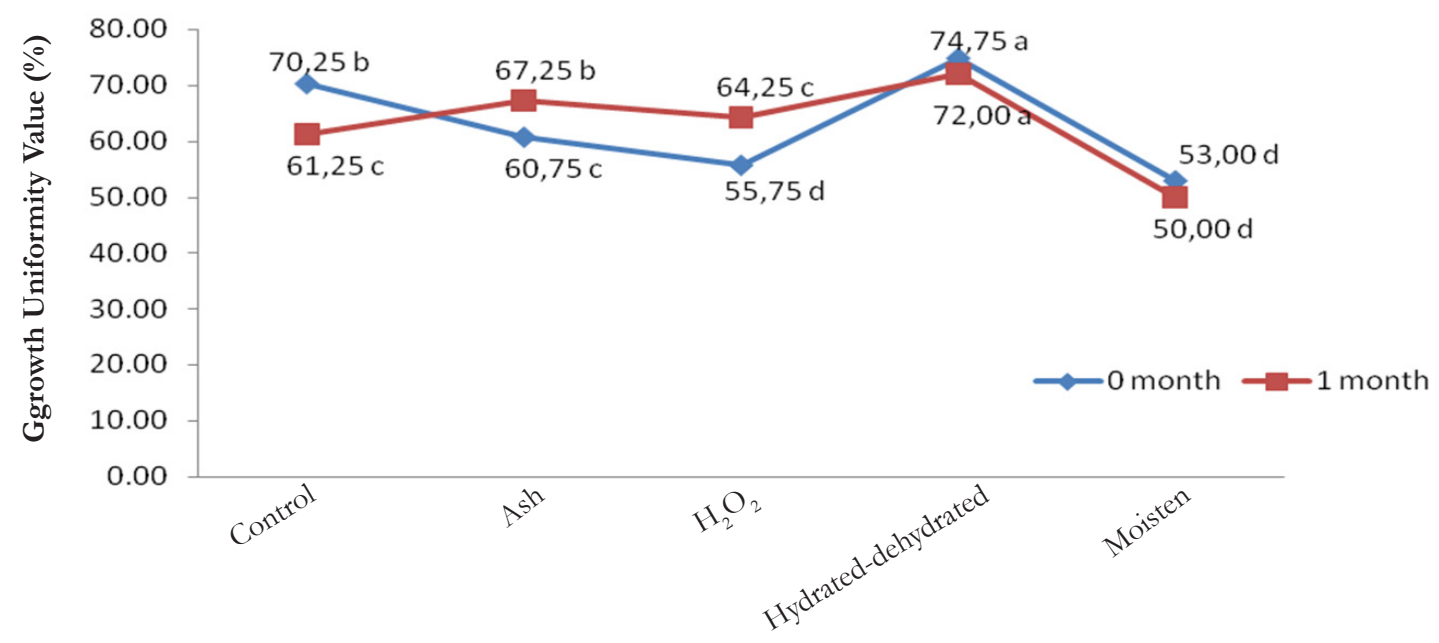

Priming treatments

Figure 5. Mean values of the growth uniformity value of Trema seeds and their differences test in relation to the priming before and after storage

Remarks: values followed by the same letters are not significantly difference at a confidence level of 95\% 
The appropriate treatment method of priming to increase the viability and vigor of trema seeds, both before and after storage is the treatment of hydration-dehydration. Before storage, the treatment can increase the value of germination percentage and speed of germination, respectively of $15 \%$ and $0.9 \%$ etmal of the control. After the storage, treatment hydration-dehydration is able to increase $17 \%$ germination percentage and $1.25 \%$ etmal of germination speed. High values of mean daily germination $(1.26 \%)$ and germination value $(1.60 \%)$ are achieved when the seeds have not been stored, whereas when the seeds have been stored there is no difference of both parameters among the treatments. In the treatments of before and after storages, it was known that the seeds treated by priming with hydrated-dehydrated method was able to produce a highest growth uniformity that is $74.75 \%$ (before storage) and $72 \%$ (after storage) compared to other treatments.

\section{ACKNOWLEDGEMENT}

The author would like to thank to Ateng Rahmat Hidayat, who had assisted us during the implementation of seed examination in the laboratory and greenhouse of Forest Tree Seed Technology Research and Development Centre.

\section{REFERENCES}

Abebe, A.T \& Modi, A.T (2009). Hydro-priming in dry bean (Phaseolus vulgaris L.). Research Journal of Seed Science, 2(2), 23-31.

Damanik, F.T. (2010). Uji keserempakan perkecambahan benih. dasar teknologi benih. Jurusan Agroekoteknologi, Fakultas Pertanian, Universitas Pertanian. Bandar Lampung.

Duffus, C.\& Slaugther, C. (1985). Las Semillas y Sus Usos; AGT editor: Mexico City, Mexico; p. 188.

Farooq, M., Basra, S.M.A., \& Khan, M.B. (2007). Seed priming improves growth of nursery seedlings and yield of transplanted rice.
Archives of Agronomy and Soil Science, 53(3), 315326.

Farooq, M., Wahid, A., Kobayashi, N., Fujita, D., \& Basra, S.M.A. (2009). Plant drought stress, effects, mechanisms and management. Agronomy for Sustainable Development, 29(1),185212.

Fujikura, Y., Kraak, H.L. \& Karssen, C.M. (1993). Hydro priming a simple and inexpensive priming method. Seed Science and Technology, 21, 639-642.

Gairola K.H., Nautiyal A. \& R., Dwivedi A.K. (2011). Effect of temperatures and germination media on seed germination of Jatropha curcas Linn. Advancesin Bioresearch, 2, 66-71.

Gholami, A., Shahsavani, S., \& Nezarat, S. (2009). The effect of plant growth promoting Rhizobacteria (PGPR) on germination, seedling growth and yield of maize. International Journal of Biological and Life Sciences, 5(1): 35-40.

Hadinezhad, P \& Payamenur, V \& Mohamadi, J \& Ghaderi-Far, Farshid. (2013). The effect of priming on seed germination and seedling growth in Quercus castaneifolia. Seed Science and Technology,41(1),121-124.doi://10.15258/ sst.2013.41.1.11.

Halimursyadah \& Murniati, E. (2008). Pengaruh pemberian senyawa antioksidan sebelum simpan terhadap umur simpan benih kapas (Gossypium hirsutum L.). Journal Floratek, 3, 1-9.

Hidayat, Y. (2007). Pengaruh waktu penyimpanan buah terhadap viabilitas benih gmelia (Gmelina arborea Roxb). Jurnal Wana Mukti, 5(1), 27-36.

Hill, H.J. (2018). Why prime seeds? Seed dynamic incorporated. Accessed in February 2018 from http://seeddynamics.com/research/ why_prime_seeds.

Ibrahim, N.D, Bhadmus, Z \& Singh, A. (2013). Hydro-priming and re-drying effects on germination, emergence and growth of upland rice (Oryza sativa L.). Nigerian Journal of Basic and Applied Science, 21(2), 157-164. doi://10.4314/njbas.v21i2.11.

Jyoti \& C.P Malik. (2013). Seed deterioration: A review. International Journal of Life Sciences Biotechnology and Pharma Research, 2(3), 374-385.

Khan, A.A. (1992). Preplant physiological seed conditioning. in Janick, J. (eds.), Horticultural Reviews (pp.131-181). New York: John Willey and Sons. 
Kurniaty, R., Yuniarti, N., Danu, \& Siregar, N. (2015). Teknik perbenihan dan pembibitan jenis alternatif penghasil energi terbarukan. (Laporan Hasil Penelitian). Bogor: Balai Penelitian dan Pengembangan Teknologi PerbenihanTanaman Hutan.

Lopez, S.A., Soriano, D., Velazquez, N., Segovia, A.O., \& Debuen, A.G. (2014). Priming effects on seed germination in Tecoma stans (Bignoniaceae) and Cordia megalantha (Boraginaceae), two tropical deciduous tree species. Acta Oecologica, 61, 65-70.

Mazibuko, T.G \& A.T Modi (2005). Regulation of water absorption by $\mathrm{Ca}^{2+}$ osmolarity alleviates cotyledonal cracking in green beans (Phaseolus vulgaris L). Seed Science \&o Technology, 33, 303313.

Mia, M.A.B., Shamsuddin, Z.H., Wahab, Z., \& Marziah, M. (2010). Effect of plant growth promoting rhizobacterial (PGPR) inoculation on growth and nitrogen incorporation of tissue-cultured Musaplantlets under nitrogenfree hydroponics condition. Australian Journal of Crop Science, 4(2), 85-90.

Moradi, A.\& Younesi, O. (2009). Effects of osmoand hydro-priming on seed parameters of grain sorghum (Sorghum bicolor L.). Australian Journal of Basic and Applied Sciences, 3(3), 1696 -1700 .

Nawaz, J., Hussain, M., Jabbar, A., Nadeem, G.A., Saiid, M., Subtain, M., \& Shabbir, I. (2013). Seed priming a technique. International Journal of Agriculture and Crop Sciences, 6(20),13731381.

Paparella, S., Araújo, S.S., Rossi, G., Wijayasinghe, M., Carbonera, D. \& Balestrazzi, A. (2015). Seed priming: state of the art and new perspectives. Plant Cell Report. 34, 1281-1293.

Panjaitan, S. (2010). Kemunduran mutu benih rekalsitran. retreived from panjaitansumitro. blogspot.com/ on 29 September 2016.

Ramesh, N. (2007). Studies on provenance, nursery mixture and pre-sowing treatments on seed quality and characterization in Pongamia. (Thesis). University of Agricultural Sciences, Dharwad.

Rostiwati, T., Heryati, Y., \& Bustomi, S. (2006). Review hasil litbang kayu energi dan turunannya. Pusat Penelitian dan Pengembangan Hutan Tanaman.

Rodríguez, R.Z, Montiel L.G.H, Amador B.M., Puente E.O. R,.Capistrán L.L, Diéguez E.T \&
Matson M.V.C (2015). Effect of hydropriming and biopriming on seed germination and growth of two mexican fir tree species in danger of extinction. Forests,(6), 3109-3122

Ruliansyah, A. (2011). Peningkatan performansi benih kacangan dengan perlakuan invigorasi. Jurnal Perkebunan \& Lahan Tropika, 1, 13-18.

Rusmin, D. (2007). Peningkatkan viabilitas benih jambu mete (Anacardium occidentale L.) melalui invigorasi. Jurnal Perkembangan Teknologi Tanaman Rempab dan Obat, 19(1), 56-63.

Schmidt, L. (2000). Pedoman penanganan benih tanaman butan tropis dan sub tropis. Direktorat Jenderal Rebabilitasi Laban dan Perbutanan Sosial Indonesia Forest Seed Project. Jakarta: Gramedia Pustaka.

Steel, R..G..D., \& Torrie, J.H.. (1995). Prinsip dan prosedur statistika. Penterjemah Bambang Sumantri. Jakarta: Gramedia Pustaka.

Tian, Y., Guan, B., Zhou, D., Yu, J., Li, G., \& Lou, Y. (2014). Responses of seed germination, seedling growth, and seed yield traits to seed pre-treatment in maize (Zea mays L.). The Scientific World Journal, Article ID 834630, 8 pages. doi://10.1155/2014/834630.

Utami, E.P., Sari, M., \& Widajati, E. (2013). Perlakuan priming benih untuk mempertahankan vigor benih kacang panjang (Vigna Unguiculata) selama penyimpanan. Bulletin Agrohorti, 1(4),75-82.

Yuanasari, B.S., Kendarini, N., \& Saptadi, D. (2015). Peningkatan viabilitas benih kedelai hitam (Glycine max L. Merr) melalui invigorasi osmoconditioning. Jurnal Produksi Tanaman, $3(6), 518-527$.

Zanzibar, M., \& Mokodompit, S. (2007). Pengaruh perlakuan hidrasi dehidrasi terhadap berbagai tingkat kemunduran perkecambahan benih damar (Agathis loranthifolia F. Salisb) dan mahoni (Swietenia macrophylla King). Jurnal Penelitian Hutan Tanaman, 4(1), 001-067.

Zanzibar, M. \& Mokodompit, S. (2007). Pengaruh perlakuan hidrasi-dehidrasi terhadap berbagai tingkat kemunduran perkecambahan benih damar dan mahoni. Jurnal Penelitian Hutan Tanaman, 4(1),1-12.

Zanzibar, M. (2008). Metode sortasi dengan perendaman dalam $\mathrm{H}_{2} \mathrm{O}$ dan hubungan antara daya berkecambah dan nilai konduktivitas pada benih tusam (Pinus merkusii Jungh Et De Vriese). Jurnal Standardisasi, 10(2), 86-92. 
Zanzibar, M. (2010). Peningkatan mutu fisiologis benih suren dengan cara priming. Jurnal Standardisasi, 12 (1), 1-6.

Zanzibar, M., Haryadi, D., \& Supardi, E. (2011). Teknik penanganan benih tanaman butan penghasil kayu pertukangan jenis Bambang Lanang (Michelia koordersiana), kayu bawang (Protium javanicum), tembesu (Fagrarea fragrans) dan gelam (Melaleuca leucadendron). (Laporan) Bogor: Balai Penelitian Teknologi Perbenihan Tanaman Hutan. Bogor.

Zanzibar, M. (2017). Tipe dormansi dan perlakuan pendahuluan untuk pematahan dormansi benih Balsa (Ochroma bicolour Rowlee). Jurnal Perbeniban Tanaman Hutan, 5(1), 51-60 
Appendix 1. The result of variance analysis of the influence of priming before storage on the capacity of germination of trema seeds

\begin{tabular}{lccccc}
\hline Source of variation & $\begin{array}{c}\text { Degree of } \\
\text { Freedom }\end{array}$ & $\begin{array}{c}\text { Sum of } \\
\text { Square }\end{array}$ & Mean Square & $\begin{array}{c}\text { F } \\
\text { calculation }\end{array}$ & F table (5\%) \\
\hline Treatment & 4 & 1484,30 & 371,08 & $9.94 *$ & 3.06 \\
Residual & 15 & 560,25 & 37,35 & & \\
Total & 19 & 2044,55 & & & \\
\hline
\end{tabular}

Remark: $*$ Significant at a confidence level of $95 \%$

Appendix 2. The result of variance analysis of the influence of priming after storage on the capacity of germination of trema seeds

\begin{tabular}{lccccc}
\hline Source of variation & $\begin{array}{c}\text { Degree of } \\
\text { Freedom }\end{array}$ & Sum of Square & Mean Square & $\begin{array}{c}\text { F } \\
\text { calculation }\end{array}$ & $\begin{array}{c}\text { F table } \\
(5 \%)\end{array}$ \\
\hline Treatment & 4 & 1765,30 & 441,33 & $6.08^{*}$ & 3,06 \\
Residual & 15 & 1089,50 & 72,63 & & \\
Total & 19 & 2854,80 & & & \\
\hline
\end{tabular}

Remark: * = Significant at a confidence level of $95 \%$

Appendix 3. The result of variance analysis of the influence of priming before storage on the speed of germination of trema seeds

\begin{tabular}{lccccc}
\hline \multicolumn{1}{c}{ Source of variation } & $\begin{array}{c}\text { Degree of } \\
\text { Freedom }\end{array}$ & Sum of Square & Mean Square & F calculation & $\begin{array}{c}\text { F table } \\
(5 \%)\end{array}$ \\
Treatment & 4 & 5,20 & 1,30 & $11.08^{*}$ & 3.06 \\
Residual & 15 & 1,76 & 0,12 & & \\
Total & 19 & 6,96 & & & \\
\hline
\end{tabular}

Remark: * = Significant at a confidence level of $95 \%$

Appendix 4. The result of variance analysis of the influence of priming after storage on the capacity of germination of trema seeds

\begin{tabular}{lccccc}
\hline Source of variation & $\begin{array}{c}\text { Degree of } \\
\text { Freedom }\end{array}$ & $\begin{array}{c}\text { Sum of } \\
\text { Square }\end{array}$ & Mean Square & $\begin{array}{c}\text { F } \\
\text { calculation }\end{array}$ & $\begin{array}{c}\text { F table } \\
(5 \%)\end{array}$ \\
\hline Treatment & 4 & 1765,30 & 441,33 & $6.08^{*}$ & 3.06 \\
Residual & 15 & 1089,50 & 72,63 & & \\
Total & 19 & 2854,80 & & & \\
\hline
\end{tabular}

Remark: * = Significant at a confidence level of $95 \%$ 
Appendix 5. The result of variance analysis of the influence of priming before storage on the mean dailly germination of trema seeds

\begin{tabular}{lccccc}
\hline Source of variation & $\begin{array}{c}\text { Degree of } \\
\text { Freedom }\end{array}$ & $\begin{array}{c}\text { Sum of } \\
\text { Square }\end{array}$ & Mean Square & $\begin{array}{c}\text { F } \\
\text { calculation }\end{array}$ & F table $(5 \%)$ \\
\hline Treatment & 4 & 0,78 & 0,20 & $17.78^{*}$ & 3.06 \\
Residual & 15 & 0,16 & 0,01 & & \\
Total & 19 & 0,95 & & & \\
\hline
\end{tabular}

Remark: * = Significant at a confidence level of $95 \%$

Appendix 6. The result of variance analysis of the influence of priming after storage on the mean dailly germination of trema seeds

\begin{tabular}{cccccc}
\hline Source of variation & $\begin{array}{c}\text { Degree of } \\
\text { Freedom }\end{array}$ & $\begin{array}{c}\text { Sum of } \\
\text { Square }\end{array}$ & Mean Square & $\begin{array}{c}\text { F } \\
\text { calculation }\end{array}$ & F table $(5 \%)$ \\
\hline Treatment & 4 & 0,11 & 0,03 & $1.62^{\text {th }}$ & 3.06 \\
Residual & 15 & 0,25 & 0,02 & & \\
Total & 19 & 0,36 & & & \\
\hline
\end{tabular}

Remark: $\mathrm{tn}=$ Not Significant at a confidence level of $95 \%$

Appendix 7. The result of variance analysis of the influence of priming before storage on the germination value of trema seeds

\begin{tabular}{cccccc}
\hline Source of variation & $\begin{array}{c}\text { Degree of } \\
\text { Freedom }\end{array}$ & $\begin{array}{c}\text { Sum of } \\
\text { Square }\end{array}$ & Mean Square & $\begin{array}{c}\text { F } \\
\text { calculation }\end{array}$ & F table $(5 \%)$ \\
\hline Treatment & 4 & 2,97 & 0,74 & $19.20^{*}$ & 3.06 \\
Residual & 15 & 0,58 & 0,04 & & \\
Total & 19 & 3,55 & & & \\
\hline
\end{tabular}

Remark: $*$ = Significant at a confidence level of $95 \%$

Appendix 8 . The result of variance analysis of the influence of priming after storage on the germination value of trema seeds

\begin{tabular}{lccccc}
\hline Source of variation & $\begin{array}{c}\text { Degree of } \\
\text { Freedom }\end{array}$ & $\begin{array}{c}\text { Sum of } \\
\text { Square }\end{array}$ & Mean Square & $\begin{array}{c}\text { F } \\
\text { calculation }\end{array}$ & F table $(5 \%)$ \\
\hline Treatment & 4 & 0,32 & 0,08 & $0.96^{\text {tn }}$ & 3.06 \\
Residual & 15 & 1,26 & 0,08 & & \\
Total & 19 & 1,58 & & & \\
\hline
\end{tabular}

Remark: $\mathrm{tn}=$ Not Significant at a confidence level of $95 \%$ 
Appendix 9. The result of variance analysis of the influence of priming before storage on the growth uniformity value of trema seeds

\begin{tabular}{lccccc}
\hline Source of variation & $\begin{array}{c}\text { Degree of } \\
\text { Freedom }\end{array}$ & $\begin{array}{c}\text { Sum of } \\
\text { Square }\end{array}$ & Mean Square & $\begin{array}{c}\text { F } \\
\text { calculation }\end{array}$ & F table (5\%) \\
\hline Treatment & 4 & 303,70 & 75,93 & $4.46^{*}$ & 3.06 \\
Residual & 15 & 255,50 & 17,03 & & \\
Total & 19 & 559,20 & & & \\
\hline
\end{tabular}

Remark: $*$ = Significant at a confidence level of $95 \%$

Appendix 10. The result of variance analysis of the influence of priming after storage on the growth uniformity value of trema seeds

\begin{tabular}{lccccc}
\hline Source of variation & $\begin{array}{c}\text { Degree of } \\
\text { Freedom }\end{array}$ & $\begin{array}{c}\text { Sum of } \\
\text { Square }\end{array}$ & Mean Square & $\begin{array}{c}\text { F } \\
\text { calculation }\end{array}$ & F table (5\%) \\
\hline Treatment & 4 & 6108,30 & 1527,08 & $23.66^{*}$ & 3.06 \\
Residual & 15 & 968,25 & 64,55 & & \\
Total & 19 & 7076,55 & & & \\
\hline
\end{tabular}

Remark: * = Significant at a confidence level of $95 \%$ 